\title{
GAMBARAN KADAR TRIGLISERIDA PADA REMAJA OBES DI KABUPATEN MINAHASA
}

\author{
${ }^{1}$ Novelina Irianti Damanik \\ ${ }^{2}$ Aaltje E. Manampiring \\ ${ }^{2}$ Fatimawali
}

\author{
${ }^{1}$ Kandidat Skripsi Fakultas Kedokteran Universitas Sam Ratulangi Manado \\ ${ }^{2}$ Bagian Kimia Fakultas Kedokteran Universitas Sam Ratulangi Manado \\ Email: novelinadamanik09136@yahoo.com
}

\begin{abstract}
Obesity is a condition with abnormal fat accumulation or excessive adipose tissue that can be detrimental to health. Central obesity has a strong correlation with insulin resistance. In a state of insulin resistance hormone sensitive lipase in adipose tissue becomes active so that triglycerides in adipose tissue lipolysis increases. Therefore, insulin resistance occurs abnormalities of serum lipid profiles a typical triglyceride levels increased. The purpose of this study was to describe the levels of triglycerides in obese adolescents in Tondano City. Crosssectional study has been done in August 2012- January 2013 with population of the student in the SMK Negeri in Tondano city, from grade one to grade three were aged 13-18 years with a simple random sampling as the technique of sampling. Measurements of weight, height, waist circumference and triglyceride levels examinations have been made. Obesity is declared if it meets the following criterias: $\mathrm{BMI} \geq 25 \mathrm{~kg} / \mathrm{m} 2$, waist circumference $>90 \mathrm{~cm}$ for men and $>80$ $\mathrm{cm}$ for women. Triglyceride levels increased whet $150 \mathrm{mg} / \mathrm{dl}$. Found in 54 samples of patients with obesity. 54 obese patients were consist of female (43 samples, 79.63\%), men (11 samples, 20.37\%). 54 samples were measured, eight samples had elevated levels of triglycerides are women (7 samples, 88\%) and men (1 samples, 12\%). Conclusion of this study found that obese women have experienced more elevated triglyceride levels than obese men. These results may be useful for prevention and treatment of obesity and elevated triglyceride levels in the early teens.
\end{abstract}

Key words: adolescent, obesity, triglyceride.

Abstrak: Obesitas merupakan suatu keadaan dengan akumulasi lemak yang tidak normal atau berlebihan di jaringan adiposa sehingga dapat mengganggu kesehatan. Obesitas sentral mempunyai korelasi yang kuat dengan resistensi insulin. Pada keadaan resistensi insulin hormone sensitive lipase di jaringan adiposa akan menjadi aktif sehingga lipolisis trigliserida di jaringan adiposa semakin meningkat. Oleh karena itu pada resistensi insulin terjadi kelainan profil lipid serum yang khas yaitu kadar trigliserida meningkat. Tujuan dari penelitian ini adalah untuk mengetahui gambaran kadar trigliserida pada remaja obes di Kota Tondano. Penelitian potong lintang di lakukan Agustus 2012- Januari 2013 dengan populasi siswa SMK Negeri di Kota Tondano dari kelas satu sampai kelas tiga yang berumur 13-18 tahun dengan teknik pengambilan sampel simple random sampling. Dilakukan pengukuran berat badan, tinggi badan, lingkar pinggang dan pemeriksaan kadar trigliserida. Obesitas dinyatakan apabila memenuhi kriteria sebagai berikut: IMT $\geq 25 \mathrm{~kg} / \mathrm{m}^{2}$, lingkar pinggang $>90 \mathrm{~cm}$ untuk laki-laki dan $>80 \mathrm{~cm}$ untuk perempuan. Kadar trigliserida meningkat apabî̀ $50 \mathrm{mg} / \mathrm{dl}$. Didapatkan 54 sampel penderita obesitas. 54 penderita obesitas adalah perempuan (43 sampel; 79,63\%), laki-laki (11 sampel; 20,37\%). 54 sampel yang diukur, 8 sampel yang mengalami peningkatan kadar trigliserida yaitu perempuan (7 sampel; 88\%) dan laki-laki (1 sampel; 12\%). Kesimpulan penelitian ini didapatkan perempuan yang obesitas lebih banyak mengalami peningkatan kadar trigliserida di bandingkan laki-laki yang obesitas. Hasil ini dapat berguna untuk tindakan 
pencegahan dan tatalaksana obesitas serta peningkatan kadar trigliserida pada remaja sejak dini.

Kata kunci: remaja, obesitas, trigliserida.

Obesitas menjadi masalah di seluruh dunia baik di negara maju maupun negara berkembang. ${ }^{1}$ Obesitas dapat terjadi pada semua usia, namun yang tersering terjadi pada tahun pertama kehidupan, usia 5-6 tahun dan pada masa remaja. ${ }^{2}$ World Health Organization (WHO) melaporkan bahwa pada tahun 2008, sekitar 1,4 milyar orang dewasa usia 20 tahun ke atas mengalami overweight. Dan prevalensi obesitas di dunia yaitu $10 \%$ pada pria dan $14 \%$ pada wanita. Angka ini mengalami peningkatan 2 kali lipat bila dibandingkan dengan tahun 1980 (5\% pada pria dan $8 \%$ pada wanita). ${ }^{3}$ Prevalensi obesitas remaja mengalami peningkatan di berbagai negara tidak terkecuali Indonesia. Tingginya prevalensi obesitas remaja disebabkan oleh adanya perubahan masukan makanan, komposisi, ketersediaan dan harganya yang mengubah pola hidup yang ada. ${ }^{4}$ Menurut data Riset Kesehatan Dasar (Riskesdas) tahun 2007, prevalensi nasional obesitas umum pada penduduk usia 15 tahun ke atas adalah 10,3\% (laki-laki 13,9\% dan perempuan 23,8\%). ${ }^{5}$ Hal ini sejalan dengan hasil Riskesdas 2010 yang menyebutkan bahwa prevalensi obesitas pada remaja (lebih dari 15 tahun) di Indonesia telah mencapai $19,1 \%{ }^{6}$ Hal tersebut juga didukung oleh penelitian yang dilakukan di SMA Negeri 1 Tondano dengan hasil pemeriksaan dari 110 siswa didapati yang obesitas sentral adalah 42 siswa atau 38\% yang terdiri dari laki-laki $14 \%$ dan perempuan $86 \%{ }^{7}$

Berdasarkan penelitian yang dilakukan pada remaja di Pekalongan, faktor resiko potensial untuk menjadi obesitas adalah kondisi ekonomi keluarga yang baik, memudahkan untuk memenuhi kebutuhan gizi keluarga. kebiasaan mengkonsumsi makanan fast food, makan camilan di waktu senggang dan mengkonsumsi lebih banyak karbohidrat dan lemak, serta kurang menyadari pentingnya olahraga bagi kesehatan terutama pencegahan kejadian obesitas. $^{8}$
Obesitas merupakan suatu penyakit multifaktorial, yang terjadi akibat akumulasi jaringan lemak berlebihan, sehingga dapat menimbulkan dampak buruk pada kesehatan dan kesejahteraan hidup berikutnya. ${ }^{9,10}$ Obesitas pada remaja menjadi masalah karena menjadi predisposisi terhadap terjadinya obesitas pada masa dewasa serta timbulnya komorbiditas metabolik. ${ }^{4}$ Komorbiditas yang sering berhubungan dengan obesitas pada populasi anak-anak adalah peningkatan tekanan darah dan dislipidemia. ${ }^{11}$ Dislipidemia merupakan suatu kondisi yang mengikuti obesitas berupa gangguan metabolisme lipid yang ditandai dengan perubahan fraksi lipid plasma. $^{12}$ Pada obesitas bisa terjadi peningkatan lipid kolesterol, trigliserida, maupun LDL-kolesterol. ${ }^{2}$ Pada penelitian terhadap anak sekolah dasar yang obes di Denpasar didapatkan hubungan lemak tubuh yang bermakna dengan indikator trigliserida saja. ${ }^{13}$

Penelitian serupa belum banyak dilakukan di Sulawesi Utara khususnya Kabupaten Minahasa yang mempunyai persentase warga yang menderita obesitas dalam jumlah yang banyak. Penelitian ini bertujuan untuk mengetahui gambaran kadar trigliserida pada remaja yang mengalami obesitas di Kabupaten Minahasa.

\section{METODE PENELITIAN}

Desain penelitian ini adalah penelitian potong lintang (cross sectional) yang bersifat observasional deskriptif. Penelitian ini dalam pelaksanaannya dari persiapan, pengumpulan data, analisis data hingga diseminarkan dilaksanakan selama bulan Agustus 2012- Januari 2013. Pengambilan sampel dilakukan di SMK Negeri 2 Tondano dan SMK Negeri 3 Tondano. Analisa sampel dilakukan di Laboratorium Klinik MANADO. Populasi dalam penelitian ini adalah siswa SMK Negeri 2 Tondano dan SMK Negeri 3 Tondano dari kelas satu sampai kelas tiga yang berumur 
13-18 tahun. Sampel dalam penelitian ini adalah siswa SMK Negeri 2 Tondano dan SMK Negeri 3 Tondano yang mengalami obesitas. Pemilihan sampel menggunakan metode simple random sampling. Kriteria inklusi adalah siswa SMK Negeri 2 Tondano dan SMK Negeri 3 Tondano usia 13-18 tahun, sebelumnya didiagnosis dengan obesitas dan yang bersedia menandatangani surat persetujuan untuk dijadikan sampel penelitian dan telah berpuasa 10-12 jam. Kriteria eksklusi siswa SMK Negeri 2 Tondano dan SMK Negeri 3 Tondano yang berumur $<13 \&>18$ tahun, menderita penyakit kronis, dan mengkonsumsi obat-obat yang dapat menurunkan dan meningkatkan kadar trigliserida. Kadar trigliserida adalah kadar yang dihasilkan dari pemeriksaan laboratorium dengan kadar tidak normât $150 \mathrm{mg} / \mathrm{dl}$ pada remaja menurut International Diabetes Federation (2005). Obesitas adalah keadaan status gizi berdasarkan indeks massa tubuh dan berada pada persentil $\geq 95$ atau $\geq 25 \mathrm{~kg} / \mathrm{m}^{2}$ kurva IMT CDC-WHO (2000). Serta memiliki lingkar pinggang $>90$ untuk pria dan $>80$ untuk wanita berdasarkan etnis asia menurut International Diabetes Federation (2005). Remaja ialah seseorang yang berusia 13-18 tahun menurut Hurlock (1991). Alat yang digunakan untuk mengukur indeks massa tubuh, lingkar pinggang, dan pengambilan sampel darah adalah timbangan elektronik, microtoise, centimeter, spuit injeksi, kapas alkohol, bendungan, plester, label nama, tabung dan alat tulis menulis. Bahan yang digunakan dalam penelitian ini adalah darah. Mengukur Indeks massa tubuh (IMT) adalah indeks antropometri dari berat badan dan tinggi badan yang dirumuskan sebagai berikut, berat badan dalam kilogram dibagi dengan tinggi badan dalam meter kuadrat. Pengukuran berat badan menggunakan timbangan elektronik. Sebelum menimbang, periksa lebih dahulu apakah alat sudah dalam keadaan seimbang (jarum menunjuk angka 0). Dilakukan dalam posisi berdiri tanpa sepatu dengan pakaian minimal. Tinggi badan diukur dalam posisi berdiri tanpa sepatu, dan telapak kaki dirapatkan, dengan punggung bersandar pada dinding. Pada posisi yang benar subjek diinstruksikan untuk menarik nafas dalamdalam dan berdiri tegak. Pada saat yang sama pengukur menekan pada tulang mastoid yang menonjol untuk menahan pada posisi saat menarik nafas dalam tadi, kemudian instruksikan untuk menghembuskan nafas dan relaksasi menurunkan bahunya. Diperlukan dua orang untuk mengukur tinggi badan, seorang mengatur posisi dan memberi instruksi pada subjek, yang lain memegang, memeriksa posisi dan mengatur alat pengukur. Lingkar pinggang diukur dalam posisi berdiri tegak dan tenang, baju atau penghalang yang dapat mengganggu pengukuran disingkirkan. Letakkan pita pengukur ditepi atas crista illiaca. Kemudian pita pengukur dilingkarkan ke sekeliling dinding perut setinggi crista illiaca. Pita pengukur jangan sampai menekan kulit terlalu ketat. Pengukuran dilakukan saat akhir dari ekspirasi normal, dan hasilnya dinyatakan dalam satuan $\mathrm{cm}$. Sampel darah diambil dengan menggunakan spuit injeksi dari vena cubiti mediana sebanyak 3cc. Sampel darah yang telah diambil kemudian dimasukkan kedalam tabung. Pemeriksaan dilakukan di Laboratorium Klinik MANADO. Sampel berpuasa (makan, cairan, obat-obatan) kecuali air putih selama 10-12 jam sebelum dilakukan pemeriksaan kadar trigliserida. Setiap subyek terpilih diberikan informed concent dan dimintakan ijin penelitian kepada pihak sekolah dan orang tua. Data yang diperoleh dikumpulkan, diolah secara manual dan komputer selanjutnya ditampilkan dalam bentuk tabel.

\section{HASIL PENELITIAN}

Pada penelitian ini, dilakukan skrining atau penyaringan terhadap 395 orang siswa untuk mendapatkan remaja obes sebagai populasi target dengan melakukan pengukuran lingkar pinggang. Populasi terjangkau adalah remaja di SMK Negeri 2 Tondano dan SMK Negeri 3 Tondano yang mengalami obesitas sebanyak 104 orang siswa yang diambil dari siswa kelas X, XI, 
XII. Dari 104 orang siswa pada populasi terjangkau diambil secara random dan didapatkan 54 orang siswa yang memenuhi kriteria inklusi dan kriteria eksklusi yang dijadikan sebagai sampel penelitian yang dianggap mewakili populasi dan subyek untuk dilakukan pemeriksaan selanjutnya yaitu pemeriksaan kadar trigliserida dalam darah. Sebelum dilakukan pengambilan darah terhadap 54 orang siswa tersebut telah dibagikan informed consent dan telah berpuasa 10-12 jam.

Tabel 1. Distribusi Kadar Trigliserida Menurut Jenis Kelamin pada Remaja Obes

\begin{tabular}{lcccccc}
\hline \multirow{2}{*}{ Jenis } & \multicolumn{3}{c}{ Kadar Trigliserida } & \multicolumn{2}{c}{ Total } \\
\cline { 2 - 6 } Kelamin & \multicolumn{2}{c}{$\geq \mathbf{1 5 0}$} & \multicolumn{2}{c}{$<\mathbf{1 5 0}$} & \multicolumn{2}{c}{ To } \\
\cline { 2 - 6 } Laki-Laki & 1 & 12 & 10 & 22 & 11 & 20,37 \\
\hline Perempuan & 7 & 88 & 36 & 78 & 43 & 79,63 \\
\hline Total & 8 & 100 & 46 & 100 & 54 & 100 \\
\hline
\end{tabular}

Berdasarkan Tabel 1di atas didapati yang mengalami peningkatan kadar trigliserida (hipertrigliserida) berjumlah 8 orang (15\%) pada siswa laki-laki sebanyak 1 orang (12\%) dan pada siswa perempuan sebanyak 7 orang (88\%) sedangkan yang memiliki kadar trigliserida dalam batas normal berjumlah 46 orang (85\%) pada siswa lakilaki sebanyak 10 orang (22\%) dan pada siswa perempuan sebanyak 36 orang (78\%).

\section{BAHASAN}

Prevalensi obesitas di seluruh dunia selalu meningkat dari tahun ke tahun. Berdasarkan penelitian yang telah dilakukan di SMK Negeri 2 Tondano dan SMK Negeri 3 Tondano didapatkan bahwa sejumlah 104 siswa (26,32\%) mengalami obesitas dari 395 subjek penelitian. Angka ini digolongkan cukup tinggi dalam menunjukkan kejadian obesitas pada suatu kelompok. Penelitian yang dilakukan Mexitalia dkk (2007) dari 407 siswa yang diperiksa didapatkan 72 siswa (17,9\%) yang mengalami obesitas. ${ }^{14}$

Obesitas adalah hasil dari faktor genetik, perilaku, lingkungan, fisiologis, sosial, dan budaya yang berakibat pada ketidakseimbangan energi dan penyimpanan lemak berlebihan. Peran dari masing-masing faktor ini telah dipelajari secara ekstensif, dan walaupun genetik memiliki peran penting dalam pengaturan berat badan, WHO Consultation on Obesity menyimpulkan bahwa faktor perilaku dan lingkungan (misalnya gaya hidup yang menetap dikombinasikan dengan masukan energi berlebihan) bertanggung jawab terhadap peningkatan kejadian obesitas secara dramatis dalam 20 tahun ini. ${ }^{15}$

Pola makan yang tidak sehat dan berlebihan secara kualitas maupun kuantitas seperti banyak dan sering makan makanan siap saji (fast food), makanan yang manis dan mempunyai nilai nutrisi rendah, serta makanan yang tinggi gula terutama gula sederhana, lemak, dan garam memiliki pengaruh yang besar untuk terjadinya obesitas. $^{4}$ Faktor-faktor yang sering ditemukan menyebabkan asupan energi melebihi kebutuhan, adalah gangguan emosional, biasanya pada remaja, dimana makanan baginya merupakan pengganti untuk mencapai kepuasan dalam upaya memperoleh kasih sayang; gaya hidup masa kini, anak suka makanan fastfood berkalori tinggi, pizza, ayam goring dengan kentang goring, es krim, aneka makanan mie. ${ }^{10}$

Penggunaan kalori yang kurang, terjadi bilamana aktivitas fisiknya kurang. ${ }^{10}$ Dari beberapa penelitian diketahui bahwa aktivitas seperti menonton televisi dan bermain video game yang lama disertai makan makanan ringan merupakan prediktor yang kuat untuk terjadinya obesitas. ${ }^{4,10}$

Peningkatan ambilan makanan dapat meningkatkan termogenesis setelah makan dan timbunan energi yang berpengaruh terhadap peningkatan massa lemak dan peningkatan sedikit masa bebas lemak yang mengakibatkan berat badan bertambah. Ambilan lemak berlebih dalam jangka waktu lama akan menyebabkan terjadinya timbunan triasilgliserol dalam jaringan lemak. ${ }^{4}$ Pada penelitian Muscatine, anak gemuk mengalami peningkatan kadar trigliserida. ${ }^{2,10}$

Dilihat dari tabel 1 prevalensi obesitas 
lebih meningkat pada remaja perempuan dengan jumlah 43 siswa (80\%) dibandingkan dengan laki-laki yang hanya berjumlah 11 siswa (20\%). Hasil ini berbanding lurus dengan data Riset Kesehatan Dasar (Riskesdas) pada tahun 2007, prevalensi obesitas pada penduduk berusiæ1 15 tahun berdasarkan IMT adalah 10,3\% (laki-laki 13,9\%, perempuan 23,8\%). Perempuan dikatakan lebih mudah mengalami obesitas akibat daripada kurangnya aktifitas fisik dibandingkan dengan golongan laki-laki. ${ }^{16}$

Tabel 1 juga menggambarkan kadar trigliserida pada remaja obes dengan jumlah 8 siswa (15\%) yang mengalami peningkatan kadar trigliserida (hipertrigliserida), terdiri dari 7 siswa (88\%) perempuan dan 1 siswa (12\%) laki-laki. Sedangkan 46 siswa (85\%) yang terdiri 36 siswa (78\%) perempuan dan 10 siswa (22\%) laki-laki memiliki kadar trigliserida dalam batas normal. Hal ini sesuai dengan penelitian Mexitalia tentang prevalensi peningkatan kadar trigliserida didapatkan pada 10,8\% anak normal dan 45,6\% anak obesitas. ${ }^{14}$ Keadaan obesitas, terutama obesitas sentral, terkait dengan sindrom metabolik atau sindrom resistensi insulin yang terdiri dari hiperinsulinemia, diabetes mellitus, hipertensi, dan dislipidemia. Resistensi insulin dapat menyebabkan hormone sensitive lipase di jaringan adipose menjadi aktif sehingga lipolisis trigliserida di jaringan adipose semakin meningkat. Keadaan ini akan menghasilkan asam lemak bebas yang berlebihan. Asam lemak bebas akan memasuki aliran darah, sebagian akan digunakan sebagai sumber energy dan sebagian akan dibawa ke hati sebagai bahan baku pembentukan trigliserida. Di hati asam lemak bebas akan menjadi trigliserida kembali dan menjadi bagian dari VLDL. VLDL yang dihasilkan pada keadaan resistensi insulin sangat kaya akan trigliserida. Oleh karena itu pada resistensi insulin terjadi kelainan profil lipid serum yang khas yaitu peningkatan kadar trigliserida. 9,17

\section{SIMPULAN}

Dari penelitian yang dilakukan pada remaja di Kabupaten Minahasa yaitu pada siswa SMK Negeri 2 Tondano dan SMK Negeri 3 Tondano maka didapatkan prevalensi remaja obes yang mengalami peningkatan kadar trigliserida (hipertrigliserida) di Kabupaten Minahasa adalah sebanyak 8 siswa (15\%).

\section{UCAPAN TERIMA KASIH}

Ucapan terima kasih disampaikan pada DR. Dr. Billy Kepel, MMedSc, Widdhi Bodhi, Ssi, Apt, dan pada semua pihak yang baik secara langsung maupun tidak langsung telah menimbulkan idea tau gagasan dalam pemikiran penulis sehingga dapat menyelesaikan artikel ini.

\section{DAFTAR PUSTAKA}

1. WHO. Obesity and Overweight. 2012 (http://www.who.int/mediacentre/factsheets/ fs311/en/). diakses pada 20 Oktober 2012.

2. Gangguan nutrisi. In: Wahab AS, editor. Ilmu Kesehatan Anak Nelson I (Edisi ke15). Jakarta: EGC, 2000; p.214-8.

3. WHO. Obesity: Situation and Trends. 2008 (http://www.who.int/gho/ncd/risk_factors/ob esity_text/en/index.html) diakses pada 20 Oktober 2012.

4. Subardja D, Cahyono HA, Moelyo AG. Obesitas pada anak. In: Batubara JRL, AAP $\mathrm{BT}$, Pulungan $\mathrm{AB}$, penyunting. Buku Ajar Endokrinologi Anak. Jakarta: Badan Penerbit IDAI, 2010; p.353-72.

5. Badan Penelitian dan Pengembangan Depkes RI. Laporan Hasil Riset Kesehatan Dasar Nasional Tahun 2007. Jakarta: Departemen Kesehatan RI; 2007.

6. Badan Penelitian dan Pengembangan Depkes RI. Laporan Hasil Riset Kesehatan Dasar Nasional Tahun 2010. Jakarta; Departemen Kesehatan RI; 2010.

7. Kemur EJ. Prevalensi sindrom metabolik pada remaja di Kota Tondano [Skripsi]. Manado: Fakultas kedokteran Universitas Sam Ratulangi; 2010.

8. Muktiharti S, Purwanto, Purnomo I, Saleh R. Faktor risiko kejadian obesitas pada remaja sma negeri 2 dan sma negeri 3 di kota Pekalongan tahun 2010 [Skripsi]. Pekalongan: Fakultas ilmu kesehatan, Universitas Pekalongan; 2010.

9. Sugondo S. Obesitas. In: Sudoyo AW, Setiyohadi B, Alwi I, Simadibrata KM, Setiati S, editor. Buku Ajar Ilmu Penyakit 
542 Jurnal e-Biomedik (eBM), Volume 1, Nomor 1, Maret 2013, hlm. 537-542

Dalam III (Edisi ke-5). Jakarta: InternalPublishing; 2009; p.1973-83.

10. Suandi IKG. Obesitas pada remaja. In: Soetjiningsih, penyunting. Tumbuh Kembang Remaja dan Permasalahannya. Jakarta: Sagung Seto, 2004; p.77-86.

11. Deckelbaum RJ, Williams CL. Childhood Obesity: The Health Issue Obesity Res. 2001;9(suppl):239s-43s.

12. Miller J, Rosenbloom A, Silverstein J. Childhood obesity. JCEM. 2004;89:4211-8.

13. Suarca K, Suandi IKG. Hubungan antara total lemak tubuh dengan profil lipid pada anak obese di sd Denpasar. CDK. 2007;34:299-303.

14. Mexitalia M, Utari A, Sakundarno M, Yamauchi T, Subagio HW, Soemantri A.
Sindrom metabolik pada remaja obesitas. M Med Indones. 2009;43:300-6.

15. Racette SB, Deusinger SB, Deusinger RH. Obesity: Overview of Prevalence, Etiology, and Treatment. Physica Therapy. 2003;83(3):276-88.

16. Power ML, Schulkin J. Sex differences in fat storage, fat metabolism,and the health risks from obesity: possible evolutionary origin. USA, Washington DC: Georgetown University School of Medicine; 2007.

17. Adam JMF. Dislipidemia. Dalam: Sudoyo AW, Setiyohadi B, Alwi I, Simadibrata KM, Setiati S, editor. Buku Ajar Ilmu Penyakit Dalam III (Edisi ke-5). Jakarta: InternalPublishing; 2009. Hal: 1984-1992. 